\title{
BIOMASS AND CARBON STOCK ESTIMATION IN VENTORY OF INDONESIAN BANANAS (M usa spp.) AND ITS POTENTIAL ROLE FOR LAND REHABILITATION
}

\author{
SETYAWAN AGUNG DANARTO* and LIA HAPSARI \\ Purvodadi BdtanicGarden- IndonesianInstituteof Säenes \\ JalanSurabaya-MalangKm 65 Purvodad, Pasunan, EastJava 6716, Indonesia
}

Received 24 February 2014/ Accepted 30 November 2015

\begin{abstract}
Bananas (Musaspp.) are widely cultivated in Indonesia. They are extensively grown in backyards, home gardens, intercropped with short term crops and also in agroforestry system. Thepotential of bananas to sequester carbon has been reported but there is limited knowledge on the performance of various cultivars. An inventory of biomass and $\mathrm{C}$-stock estimation on banana accessions has been conducted in Musagermplasm plots - Purwodadi Botanic G arden, Pasuruan. Estimation on biomass and C-stock have been conducted for 42 individual banana accessions, comprised 5 wild banana species and 37 cultivars using non-destructive method i.e. allometric equation for banana. The objectives of this study were to conduct inventory on the biomass and C-stock estimation of Indonesian bananas in germplasm collection of Purwodadi Botanic Garden, to make the projections of time average above ground for Cstock of banana farming system in Indonesia and to discuss the potential role of bananas in land rehabilitation. The results showed that estimation value of biomass and $\mathrm{C}$-stock varied from one bananaaccession to ano ther. Wild Musa balbisiamaspecies had higher biomass and C-stock value than wild Musaaaminataspecies. Banana cultivars containing one or two " $\mathrm{B}$ " genome (ABB and AAB) were more vigorous and contributed higher biomass and C-stock than AAA and AA cultivars. Among cultivars, the highest C-stock was contributed by Pisang Kepok Bung (average of $6.92 \mathrm{~kg}$ $\mathrm{C} /$ plant) whereas the lowest C-stock was contributed by Pisang Rayap (average of $0.67 \mathrm{~kg} \mathrm{C} /$ plant). In average, various Indonesian bananas studied contributed around $2.26 \mathrm{~kg} \mathrm{C} /$ plant or 0.98 tonnes $\mathrm{C} / \mathrm{ha}$. The growing area of bananas increased from 73,539 ha in 2000 to 101,822 ha in 2010, which was decreased to 100,600 ha in 2014, contributing C-stock around 72.28 tonnes $C$ in 2000 increasing to 100.07 tonnes $C$ in 2010 with a decrease to 98.97 tonnes $C$ in 2014. These numbers are still limited only to the recorded areas. Banana plants in combination with woody tree crops, are potential as important component of agroforestry, home gardens and mixed farming systems to rehabilitate and reforest landscape, to decrease carbon emission in atmosphere in the form of biomass and Cstocks and to meet the economic needs for local surrounding community.
\end{abstract}

Keywords: banana, biomass, carbon stock (C-stock), estimation, Musa aaminata, Musa ballisiana, Purwodadi Botanic Garden, rehabilitation

\section{INTRODUCTION}

Climate change is an environmental issue that has always been discussed. Climate change is caused by energy absorbed from sun as short wave then reflected in atmosphere as infrared long wave radiation. G reenhouse gases effect absorbs infrared radiation which is retained in atmosphere as heat energy causing the increase of the earth's temperature, therefore, efforts to mitigate greenhouse gases are needed (Saharjo \& Wardhana 2011). In 2003, World Bank stated that

\footnotetext{
* Corresponding author : setyawan.10535@gmail.com
}

the earth's $\mathrm{CO}_{2}$ concentration wasabout 27 billion metric ton, which was a $19 \%$ increase from the year 1990. IPCC (2014) noted that the earth's temperature from 1880 to 2012 showed an increase from $0.65{ }^{\circ} \mathrm{C}$ to $1.06{ }^{\circ} \mathrm{C}$. A study by Ollivier \& al. (2014) reported that countries contributing a large amount of $\mathrm{CO}_{2}$ in atmosphere were China (29\%), USA (15\%), European Union (11\%), India (4.4\%), Brazil $(6.2 \%)$ and Indonesia (2.3\%). The peat and forests fires in Indonesia were estimated responsible for the released of $\mathrm{CO}_{2}$ emission to the atmosphere about 0.81 G $\mathrm{C}$ to $2.57 \mathrm{G} \mathrm{t} \mathrm{C}$ in 1997 (Page \& al. 2002). Particular in Borneo 
Island, the annual average carbon emission from forest fires was estimated about 0.02 to $0.06 \mathrm{G} \mathrm{tC}$ peryear (Kuntoro \&al. 2015).

Process of decreasing $\mathrm{CO}_{2}$ amount in the atmosphere through the process of plant photosynthesis is called carbon sequestration. In the photosynthetic process, $\mathrm{CO}_{2}$ in the atmosphere is absorbed by plant, transformed to carbohydrates compound and dispersed to all parts of plant. Carbon sequestration describes long-term storage of $\mathrm{CO}_{2}$ or other forms of carbon to either mitigate or defer global warming and avoid dangerous climate change. It has been proposed as a way to slow the atmospheric greenhouse gases, which are released by burning fossil fuels (Hairiah \& Rahayu 2007). Therefore, it is important to conduct study to examine the ability of different plant species to absorb carbon, especially in the climate change mitigation efforts.

Agroforestry system is a cultivation practice combining trees and annual crop or other farm activities adopted by smallholders to meet their needs for food, medicine, timber, fuel, fodder and market commodities. It also provides valuable environmental services such as soil fertility replenishment, water catchment protection, carbon sequestration, biodiversity conservation and landscape restoration (Garrity 2004). Bananas (Musa spp.) are extensively grown in backyards, home gardens, agroforestry system and are intercropped with short term crops. Bananas are the most favorite plants grown in agroforestry system intercropped with other important tree crops commodities (coffee, cacao, rubber), fruit trees and timber. About 9.5\% of bananas species occur in home gardens system contributing to the ecosystem services. O nly a handful of individual smallholder agroforestry systems store small amount of carbon per area, while the basic systems store as much carbon as several secondary forests (Roshetko \&al. 2002).

The potential of bananas to sequester carbon has been reported by Daphine (2014) on East African Highland bananas, but there is limited knowledge on the performance of various cultivars in Indonesia. Being part of the primary center of origin and diversity so that has large number of bananas (Musaceae) both wild seeded species and edible seedless or cultivar with many local names and synonimies (Espino \& al. 1992; Valmayor \& al. 2000). There is no less than 200 local cultivars cultivated and developed across Indonesia archipelago (Nasution \& Yamada 2001). The objectives of this study were to conduct inventory on the biomass and C-stock estimation of Indonesian bananas in germplasm collection of Purwodadi Botanic Garden, to make the projections of time average above ground for C-stock of banana farming system in Indonesia and to discuss the potential role of bananas in land rehabilitation.

\section{MATERIALS AND METHODS}

\section{Study Site}

The study was conducted at banana collection plots of Purwodadi Botanic G arden - Indonesian Institute of Sciences from April to May 2012. Purwodadi Botanic Garden has a collection of Musagermplasm both wild species and cultivated varieties through exploration, plant exchange, grants and community or personal contribution from several regions all over Indonesia, mostly from Eastern Indonesia. Current collections in 2014 is about 134 accessions comprised 7 wild speciesand 127 cultivated varieties.

\section{Materials}

The materials studied were 42 selected banana accessions of Purwodadi Botanic Garden collections comprised 5 wild species and 37 cultivars. The diameter at breast height (DBH) of the individual pseudostem was measured at mature age (already flowering) using tape meter with minimum of two replications per accession. As reported by D aphine (2014) that C-stock of banana plants was significantly influenced by growth stages in which maturity stage was the optimal stage to be measured (D aphine 2014).

\section{Biomass and C-Stock Estimation}

Biomass was estimated using non-destructive method i.e. allometric equation for banana (Kurniawan $\notin$ al. 2010) and then C-stock was estimated by crossing its biomass to average value of C-stock in plants which is 0.46 (Hairiah $\notin$ al. 2010). The development of allometric equations has been investigated based on specific condition, species and or plant communities (Ketterings \&al. 2001; Wibowo \&al. 2010): 
$\mathrm{Y}=0.0303 \times \mathrm{D}^{2.1345}$

$\mathrm{Z}=\mathrm{Y} \times 0.46$

where:

$\mathrm{Y}=$ Plant biomass $(\mathrm{kg})$

$\mathrm{D}=$ D iameter at breast high $(\mathrm{cm})$

$\mathrm{Z}=\mathrm{C}$-stock $(\mathrm{kgC} /$ plant $)$.

\section{RESULTSAN D DISCUSSION}

Biomass in plants was affected by interaction of genetic and environmental factor. In this study, the Purwodadi Botanic Garden provides homogenous environmental condition, i.e. soil type, water supplies and culture practices. Therefore, the biomass results were mostly affected by its genetic factor. The results showed that the estimation value of biomass and $\mathrm{C}$-stock tended to vary from one banana accession to another. Pseudostem D BH was confirmed as the best predictor for biomass estimation in banana plants and it is recommended to be used in most carbon related studies. The more vigorous banana plants contribute higher estimation value of biomass and C-stock (Fig. 1).

C-stock level is related to plant photosynthesis process. Based on its photosynthesis pathway, banana plants are classified as C3 plant. In C3 plants, $\mathrm{CO}_{2}$ and water from the environment are enzymatically combined with a five-carbon acceptor molecule to contribute two molecules of a three-carbon intermediate. C3 plants respond favorably to higher concentrations of carbon dioxide than C4 and CAM. C4 plants include corn, sugar cane and many other tropical grasses, whereas CAM plants include orchids, bromeliad and succulent plants (Taiz \& Z eiger 2002).

\section{Biomass and C-stock Inventory Results in Wild Banana Species}

Wild bananas are pioneer plants and can grow in various conditions. It commonly grows wild in the forests, road sides and river banks. Wild Musa ballisiana species is also being cultivated by farmers to get the leaves for various wrapping purposes. The immature fruits are also edible for any traditional side dishes. Wild Musaaaminatais rarely cultivated. There are also some other species of bananas (not studied here) such as Musa velutina Musa amata, Musa borneenisetc. that are commonly cultivated for ornamentals due to its beautiful performances (Nasution \& Yamada 2001; Hapsari \&al. 2015a).

Among the wild species studied, Musa ballbisianaspecies contributes much higher level of biomass and C-stock estimation than Musa aaminata species (Table 1). Musa balbisiana is considered to be more vigorous and robust, as well as drought and disease resistant, while Musa aaminataspecies is slender but has more attractive morphology (Daniells \& al. 2001; Nasution \& Yamada 2001). Musa ballisiana species (Pisang

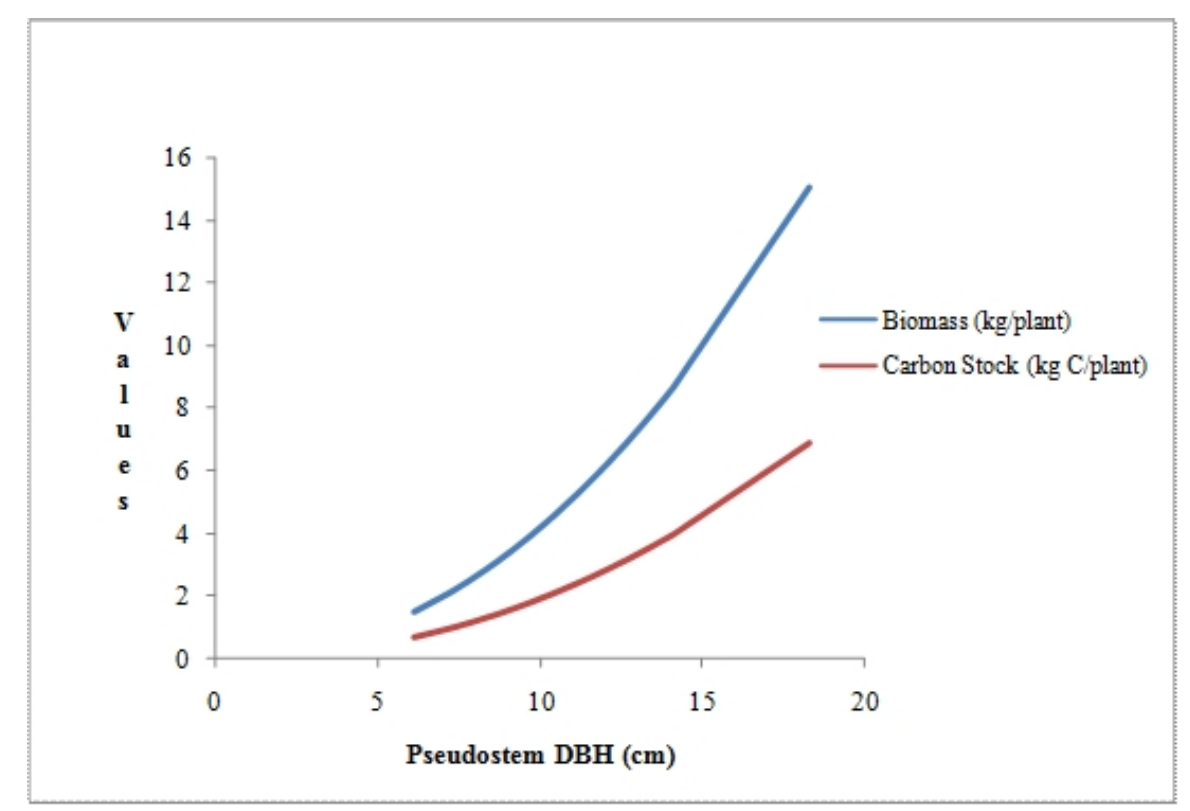

Figure 1 Positive correlation of pseudostem D BH to biomass and C-stock values in banana plants 
Table 1 Pseudostem D BH, biomass and carbon stock estimation of wild banana species

\begin{tabular}{lllll}
\hline Species & Local name & $\begin{array}{l}\text { Pseudostem } \\
\text { D BH }(\mathrm{cm})\end{array}$ & $\begin{array}{l}\text { Biomass } \\
(\mathrm{kg} / \text { plant })\end{array}$ & $\begin{array}{l}\text { C-stock } \\
\text { (kg C/ plant) }\end{array}$ \\
\hline Musa ballbisiana & Klutuk Wulung & 21.47 & 21.09 & 9.70 \\
Musa ballbisiama & Klutuk Ijo & 15.35 & 10.30 & 4.74 \\
Musa aaminata var. alasensis & Pisang Hutan & 6.78 & 1.80 & 0.83 \\
Musa aaminata var. nutilifes & Pisang Cici Hutan & 4.99 & 0.94 & 0.43 \\
Musa aaminata var. tomentosa & Unti D arek & 7.07 & 1.97 & 0.91 \\
\hline
\end{tabular}

Klutuk Wulung) has large pseudostem diameter $(21.47 \mathrm{~cm})$ contributing around $21.09 \mathrm{~kg} /$ plant biomass and around $9.7 \mathrm{~kg} /$ plant C-stock. $\mathrm{M}$ aaminata var. nutilifes with slender pseudostem $(4.99 \mathrm{~cm})$ contributed around $0.94 \mathrm{~kg} /$ plant biomass and around $0.43 \mathrm{~kg} \mathrm{C} /$ plant C-stock (Table 1).

\section{Biomass and C-stock Inventory Results in Various Banana Cultivars}

Edible banana cultivars have lower biomass and C-stock values than wild bananas. The genetic composition of Musabalbisianais the combination of wild Musa aaminata (donor A genome) and Musa balbisiana (donor B genome). Genomic composition can be identified using morphology (Jumari \& Pudjoarinto 2000) and genetic (Hapsari \& al. 2015b). Banana cultivars containing one or two "B" genome (ABB and AAB cultivars) are more vigorous and contribute higher biomass and C-stock than the AAA and AA cultivars.

Pisang Kepok Bung (ABB) is the most vigorous cultivar with pseudostem diameter of $18.32 \mathrm{~cm}$ contributing around $15.04 \mathrm{~kg} /$ plant biomass and around $6.92 \mathrm{~kg} \mathrm{C} /$ plant C-stock. Pisang Rayap (AA) is the most slender cultivar with pseudostem diameter of $6.14 \mathrm{~cm}$ contributing around $1.46 \mathrm{~kg} /$ plant biomass and around $0.67 \mathrm{~kg} \mathrm{C} /$ plant C-stock. Pisang Triolin having $\mathrm{AAB}$ genome contributed biomass and C-stock values in between Pisang Kepok Bung (ABB) and Pisang Rayap (AA) (Fig. 2). The average value of $\mathrm{C}$-stock contributed by banana plants per genome group from the highest to the lowest values are as follows: $\mathrm{BB}$ wild $(7.22 \mathrm{~kg}$ $\mathrm{C} /$ plant), $\mathrm{ABB}$ cultivars (2.74 $\mathrm{kg} \mathrm{C} /$ plant), $\mathrm{AAB}$ cultivars (2.11 kg C/ plant), AAA cultivars $(1.73 \mathrm{~kg}$ $\mathrm{C} /$ plant), $\mathrm{AA}$ cultivars (1.55 kg C/ plant) and $\mathrm{AA}$ wild $(0.72 \mathrm{kgC} /$ plant).

In traditional home gardens and in agroforestry, farmers plant various local cultivars. However, the commercial scale farmers plant bananas cultivars based on consumers' preference and agroclimate condition in an area. Pisang Kepok (ABB) is the most favorite cultivar to be cooked, while Pisang Raja (AAB), Pisang Ambon (AAA) and Pisang Mas (AA) are often processed for dessert. Wild species and cultivars studied contributed an average of $2.26 \mathrm{~kg} \mathrm{C} /$ plant Cstock.

\section{Time Average C-Stock in Banana Farming System in Indonesia}

Banana farming system recognizes 3 different planting distances based on its canopy sizes, i.e. $6 \times 6 \mathrm{~m}$ for wide canopy, $5 \times 5 \mathrm{~m}$ for medium canopy and $4 \times 4 \mathrm{~m}$ for small canopy (Cahyono 1996). Banana plants may contribute an average of $0.98 \mathrm{C}$ tonnes/ha C-stock. This number is quite high if compared to C-stock contributed by understory of agroforestry system which only contributed 0.2-0.3 C tonnes/ ha. However, agroforestry of coffea plants contributed higher C-stock than banana plants, i.e. 2.0-12.0 C tonnes/ ha (FORDA 2010).

The growing area of bananas increased from 73,539 ha in 2000 to 101,822 ha in 2010, which was decreased to 100,600 ha in 2014 (Ministry of Agriculture 2015), contributing C-stock around 72.28 tonnes $C$ in 2000 increasing to 100.07 tonnes $C$ in 2010 with a decrease to 98.97 tonnes $\mathrm{C}$ in 2014. These numbers are still limited only to the recorded areas.

\section{Potential Role of Banana Plants for Land Rehabilitation}

Tropical forests in Southeast Asia are constantly changing as a result of logging and land conversion such as logging activities, complete deforestation, conversion from forest to grassland or annual crops, tree plantations and other woody perennial crops (Lasco 2002; Monde 2009). Those vast area of degraded land are in need of rehabilitation. A groforestry system may become an approach to prevent deforestation by 


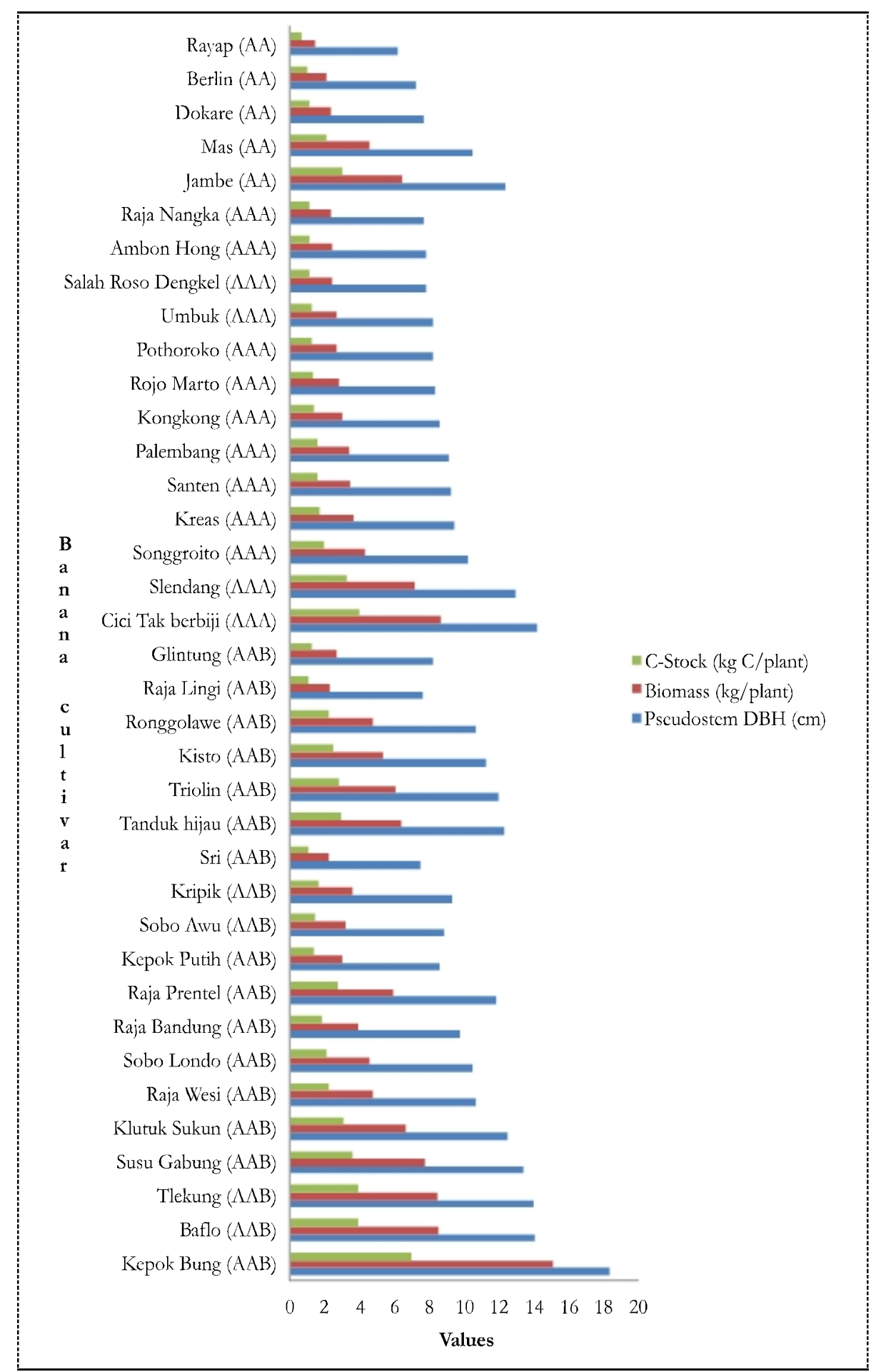

Figure 2 Pseudostem DBH, biomass and C-stock estimation of various Indonesian banana cultivars

providing on-farm trees sources. Agroforestry system provides better carbon storage than the usual annual crops farming system because agroforestry system intercropped trees with annual crops, continuously giving much higher biomass and litters in varied quality (Utami \&al. 2003).

Home garden as smaller level of agroforestry is species rich and tree-based system producing wood and non-wood products and therefore, producing high biomass. D ue to high biomass produced, this system potentially offers carbon storage. In terms of aboveground biomass, home garden contains more carbon per hectare than Imperata grasslands, cassava fields and young rubber agroforestry (Roshetko $\notin$ al. 2002). 
Table 2 Time average C-Stock in Indonesia banana farming systems in 2000-2014

\begin{tabular}{lccccc}
\hline \multirow{2}{*}{ Planting distance } & $\begin{array}{c}\text { Number of } \\
\text { plants/ ha }\end{array}$ & $\begin{array}{c}\text { C-Stock } \\
\text { (C kg/ ha) }\end{array}$ & \multicolumn{3}{c}{ Time average C-stock contribution } \\
\cline { 4 - 6 } & & & Year 2000 & Year 2010 & Year 2014 \\
(C tonnes) & (C tonnes) & (C tonnes) \\
\hline Wide canopy 6 x 6 m & 278 & 628.67 & 46.23 & 64.01 & 63.24 \\
Medium canopy 5 x 5 m & 400 & 905.29 & 66.57 & 92.18 & 91.07 \\
Narrow canopy 4 x 4 m & 625 & $1,414.52$ & 104.02 & 144.03 & 142.30 \\
\hline Average & 434 & 982.83 & 72.28 & 100.07 & 98.87 \\
\hline
\end{tabular}

Banana as a component of mixed agroforestry system has moderate C-stock contribution. This study showed that one hectare of banana plants store more carbon ( 0.98 tonnes) than cassava ( 0.5 tonnes) and Imperata grassland (0.7 tonnes) (Hairiah 1997).

Banana plants store much less carbon than perennial woody plants or trees, however, banana has high economic value and provide shades to tree crops commodities (coffee, cacao, rubber), fruit and timber (Roshetko \& al. 2002). Also, banana plants produce fruit all year round which continuously contribute food to smallholder farmers in the area (Hapsari 2011).

The role of agroforestry in absorbing $\mathrm{CO}_{2}$ as well as in storing and maintaining carbon stocks is lower than that of natural forests, but this system can increase carbon stocks on degraded lands (Widianto etal. 2003).

\section{CONCLUSIONS}

Banana accessions contributed varied estimated value of biomass and C-stock per accessions depending on their characteristics performance. Pseudostem DBH was confirmed as the best predictor for biomass estimation in banana plants and it is recommended to be used in most carbon related studies. The more vigorous banana plants contribute higher estimation value of biomass and C-stock. The C-stock value ranged from $0.67 \mathrm{~kg} \mathrm{C} /$ plant to $6.92 \mathrm{~kg} \mathrm{C} /$ plant. In average, various Indonesian bananas studied contributed around $2.26 \mathrm{~kg} \mathrm{C} /$ plant or 0.98 tonnes $\mathrm{C} / \mathrm{ha}$. The growing area of bananas increased from 73,539 ha in 2000 to 101,822 ha in 2010, which was decreased to 100,600 ha in 2014, contributing C-stock around 72.28 tonnes $\mathrm{C}$ in 2000 increasing to 100.07 tonnes $C$ in 2010 and decreasing to 98.97 tonnes $C$ in 2014. Agroforestry is species rich and tree-based system producing wood and non-wood products and therefore, producing high biomass. Due to high biomass produced, this system potentially offers carbon storage. Banana plants in combination with woody tree crops, are potential as important component of agroforestry, home gardens and mixed farming systems to rehabilitate and reforest landscape, to decrease carbon emission in atmosphere in the form of biomass and C-stocks and to meet the economic needs for local surrounding community.

\section{ACKNOWLEDGEMENTS}

The authors would like to acknowledge Ahmad Masrum and Lamiran for their technical guidance during the study observation in banana collection field of Purwodadi Botanic $\mathrm{G}$ arden.

\section{REFERENCES}

Cahyono B. 1996. Pisang(Budidaya danA Analisis Usaha Tani). Yogyakarta (ID ): Kanisius. p 80.

Daniells J, Jenny C, Karamura D, Tomekpe K. 2001. Musalogue a Catalogre of Musa Gemplasm Divesityin the Gerus Musa Montpellier (FR): International Network for the Improvement of Banana and Plantain (INIBAP). The International Plant G enetic ResourcesInstitute(IPG RI).

D aphine K. 2014. Carbon Sequestration potential of East African highland banana cultivars in Uganda. Dissetation Kampala(UG): Makerere University.

Espino RRC, Jamaludin SH, Silayoi B, Nasution RE. 1992. MusaL. (edible cultivars). In: Verheij EWM, Coronel R.E, editors. Plant Resaures of Sath-East Asia No2, Edilde Fnits and Nuts Bogor (ID): PROSEA Foundation. p225-33.

Forestry Research and Development Agency. 2010. Cadangan Karbon pada Bebacai Tipe Hutan dan Jevis Tanaman di Indonesia Bogor (ID): Pusat Penelitian dan Pengembangan Perubahan Iklim dan Kebijakan. 
Garrity DP. 2004. A groforestry and the achievement of the Millennium Development Goals. Agrofor Sys 61:5-17.

Hairiah K. 1997. Final repat: CarbonStak inVariasLand-use systems in Lampung and Jambi. Bogor (ID): International Centre for Research in Agroforestry (ICRAF).

Hairiah K, Rahayu S. 2007. Pengukuran Karbon Tesimpan di Bebacai MacamPenganaanLahan Bogor (ID): World Agroforestry Centre(ICRAF).

Hairiah K, Dewi S, Agus F, Velarde S, Ekadinata A, Rahayu S, van Noordwijk M. 2010. A manual: Measuing Carbon Stodks Across Land Use Systems Bogor (ID): World Agroforestry Centre(ICRAF). p 154.

Hapsari L. 2011. Indonesian banana cultivars Purwodadi Botanic Garden's collection. In: International Conference on Food Safety \& Food Security. Proceedings: 2010 Dec 1-Dec 2; Yogyakarta (ID): Gajah Mada University. p115-9.

Hapsari L, Masrum, A, Lestari DA. 2015a. Diversity of bananas (Musa spp.) in Madura Island, East Java: exploration and inventory.J Bio \& Env Sci 6(3): 25664.

Hapsari L, Wahyudi D, Azrianingsih R, Arumningtyas EL. 2015b. Genomic Identification of bananas (Musa spp.) from East Java assesed by PCR-RFLP of the Internal Transcribed Spacer ribosomal D NA. Int J Biosci 7(3): 42-52.

Intergovernmental Panel on Climate Change (IPCC). 2014. Synthesis Repat: ClimateChange2014 G eneva (CH): IPCC.p 151.

Jumari, Pudjoarinto A. 2000. Kekerabatan fenetik kultivar pisang diJawa. Biologi 2(9):531-42.

Ketterings Q M, Coe R, van Noordwijk M, Ambagau Y, Palm CA. 2001. Reducing uncertainty in the use of allometric biomass equations for predicting aboveground trees biomass in mixed secondary forest. Forest EcolManage 146: 199-209.

Kuntoro AA, Wahyu A, Hendri. 2015. Estimation of total carbon emission from forest fires: case study of Borneo Island. In:The Thind Joint Seminar of Japan and Indonesia Environmental Sustainability and Disaster Prevention ( $3^{\text {rd }}$ ESD P 2015). Proceedings: November 25 2015; Bandung (ID): Institut Teknologi Bandung.p 29-37.

Kurniawan S, Prayogo C, Widianto, Zulkarnaen MT, Lestari ND, Aini FK, Hairiah K. 2010. Working paper: Estimas Karbon Tesimpan di Lahantlahan Petarian di DAS Konto, Jana Timr RACSA (Rapid Carbon Stok Appraisal). Bogor (ID): World Agroforestry Centre (ICRAF).

Lasco RD. 2002. Forest carbon budgets in Southeast Asia following harvesting and land cover change. Sc in China 45C:55-64.
Ministry of Agriculture Republic Indonesia [Internet]. 2015. [cited 2015 Dec 4]. Available from: http:/ / aplikasi.pertanian.go.id/ bdsp/ hasil_ko m.asp.

Monde A. 2009. D egradation of carbon as a result of land forest use change to cocoa plantations in Nopu Watershed, Central Sulawesi. J Agroland $16(2): 110-7$.

Nasution RE, Yamada I. 2001. Pisangfisang Liar di Indonesia Bogor (ID): Puslitbang - Biologi LIPI.

O llivier JGJ, Janssens-Maenhout G, Muntean M, Peters JAHW. 2014. Trends in Gldbel $\mathrm{CO}_{2}$ Emissions 2014 Repat The Hague (NL): PBL (Planbureau voor de Leefomgeving)/ The Netherland Environmental AssesmentAgency. p 59.

Page SE, Siegert F, Rieley JO, Boehm HDV, Jaya A, Limin S. 2002. The amount of carbon released from peat and forest fires in Indonesia during 1997. Nature 420:61-5.

Roshetko JM, D elaney M, Hairiah K, Purnomosidhi P. 2002. Carbon stock in Indonesian home garden systems: can smallholder systems be targeted for increased carbon storage? Am J of AltAgr 17(2): 1-11.

Saharjo BH, Wardhana HFP. 2011. Pendugaan potensi simpanan karbon pada tegakan pinus (Pinus mokusii Jungh EtdeVrieed di KPH CianjurPerum Perhutani Unit III Jawa Barat dan Banten. J SilvikultTrop 3(1):96-100.

Taiz L, Zeiger E. 2002. Plant Physidogy. Sunderland (UK): Sinnaeur A ssociate, Sunderland.

Utami SR, Verbist B, van Noordwjik M, Hairiah K, Sardjono MA. 2003. Prospok Penditian dan PengembanganA groforesti di Indonesia Bogor (ID ): World Agroforestry Center (ICRAF). SEA Regional O ffice. p 22.

Valmayor RV, Jamaluddin SH, Silayoi B, Kusumo S, Danh LD, Pascua OC, Espino RRC. 2000. Banama Cultivar Names and Synonyms in Sathest Asia Los Banos, Laguna (PH): International Network for the Improvement of Banana and Plantain (INIBAP).

Wibowo A, Ginoga $\mathrm{K}$, Nurfatriani $\mathrm{F}$, Indartik, D wiprabowo $\mathrm{H}$, Ekawati S, Krisnawati $\mathrm{H}$, Siregar CA. 2010. REDD and Foret Goumane Bogor (ID): Pusat Penelitian Sosial Ekonomi dan Kebijakan Kehutanan. Badan Penelitian dan Pengembangan Kehutanan. Kementerian Kehutanan RI.

Widianto, Hairiah K, Suharjito D, Sardjono MA. 2003. Fungsi dan Peran Agroforestri. Bogor (ID): World Agroforestry Center (ICRAF). SEA Regional Office. $\mathrm{p} 39$. 